$\underline{R E V I E W}$

\title{
Occupational asthma caused by natural rubber latex
}

\author{
O. Vandenplas
}

Occupational asthma caused by natural rubber latex. O. Vandenplas. CERS Journals Ltd.

ABSTRACT: IgE-mediated sensitization to protein allergens of natural rubber latex (NRL) can induce immediate hypersensitivity reactions ranging from mild urticaria to life-threatening anaphylaxis after cutaneous, mucosal or visceral exposure. Elutable allergens from NRL gloves adsorb to the cornstarch powder particles, become airborne, and have the potential to cause respiratory reactions.

Recent studies indicate that asthma is a frequent manifestation of NRL allergy among workers manufacturing NRL materials and among health-care providers using NRL gloves. NRL-induced asthma should receive increasing attention as it can lead to permanent respiratory sequelae and occupational disability. The need for early and accurate diagnosis is outlined and the different diagnostic approaches are reviewed. Specific issues pertaining to the management of affected subjects and to the prevention of exposure to airborne NRL are discussed.

Areas of future research should include: 1) further characterization of relevant NRL allergens; 2) development and validation of methods for quantitative assessment of allergen content in NRL devices and workplace environments; 3) standardization of allergen extracts used for diagnostic purposes; 4) prospective evaluation of the natural history and risk factors of NRL-induced asthma; and 5) analysis of effectiveness and cost of preventive strategies.

Eur Respir J., 1995, 8, 1957-1965.
Dept of Chest Medicine, Mont-Godinne Hospital, Catholic University of Louvain, Yvoir, Belgium.

Correspondence: O. Vandenplas Department of Chest Medicine University Hospital of Mont-Godinne 5530-Yvoir

Belgium

Keywords: Asthma

latex

occupational disease

Received: January 271995

Accepted after revision May 91995
Over the last decade, immunoglobulin E (IgE)-mediated allergy to natural rubber latex (NRL) has been increasingly recognized as a rapidly emerging public health problem, as recently reviewed [1, 2]. Individuals with allergy to NRL products may exhibit a wide range of immediate reactions, from mild contact urticaria to severe anaphylaxis. Asthma may be part of a systemic reaction following contact with NRL, or may result from inhalation of NRL allergens. Although, a number of clinical and research papers on NRL allergy have been published in recent years, relatively few studies [3-16] have specifically addressed the problems raised by asthma due to airborne NRL. However, NRL-induced asthma should receive further medical attention, because it can lead to permanent functional impairment and occupational disability. Furthermore, asthma is a frequent manifestation of NRL allergy and represents a significant cause of occupational respiratory disease among workers exposed to airborne NRL, especially health-care providers. This review will focus on specific aspects of NRL-induced asthma, with particular attention to pathophysiological mechanisms, epidemiology, diagnosis, management and prevention.

\section{Natural rubber latex}

NRL is widely used in the manufacturing of medical devices (gloves, catheters, drainage tubes, anaesthetic masks, dental dams), as well as in a variety of everyday articles (household gloves, toys, balloons, condoms, baby pacifiers, sports equipment, tyres, adhesives).

\section{Composition}

In the chemical industry's nomenclature, the term latex applies to any emulsion of polymers, including synthetic rubbers and plastics. Natural rubber latex refers specifically to products derived from the milky fluid, or latex, produced by the laticiferous cells of the tropical rubber tree Hevea braziliensis (family of Euphorbiaceae) [17]. NRL consists of three main components: rubber particles and lutoids dispersed in an aqueous serum (cytosol). Rubber particles are spherical droplets containing polymers of cis-1,4 polyisoprene (fig. 1) coated with a layer of hydrophylic colloid (proteins, lipids and phospholipids). Lutoids are vacuoles with a low internal $\mathrm{pH}$ that are involved in the coagulation of latex through the release of proteins interacting with rubber particles. Fresh NRL consists of about $30-40 \%$ rubber hydrocarbon and $2-3 \%$ proteins. Two proteins involved in the polymerization of isoprene molecules have been identified and sequenced: prenyltransferase (38 kDa), present both free in the cytosol as well as in association with rubber particles, and rubber elongation factor (REF) (14 kDa), bound to rubber particles [18]. Hevein 

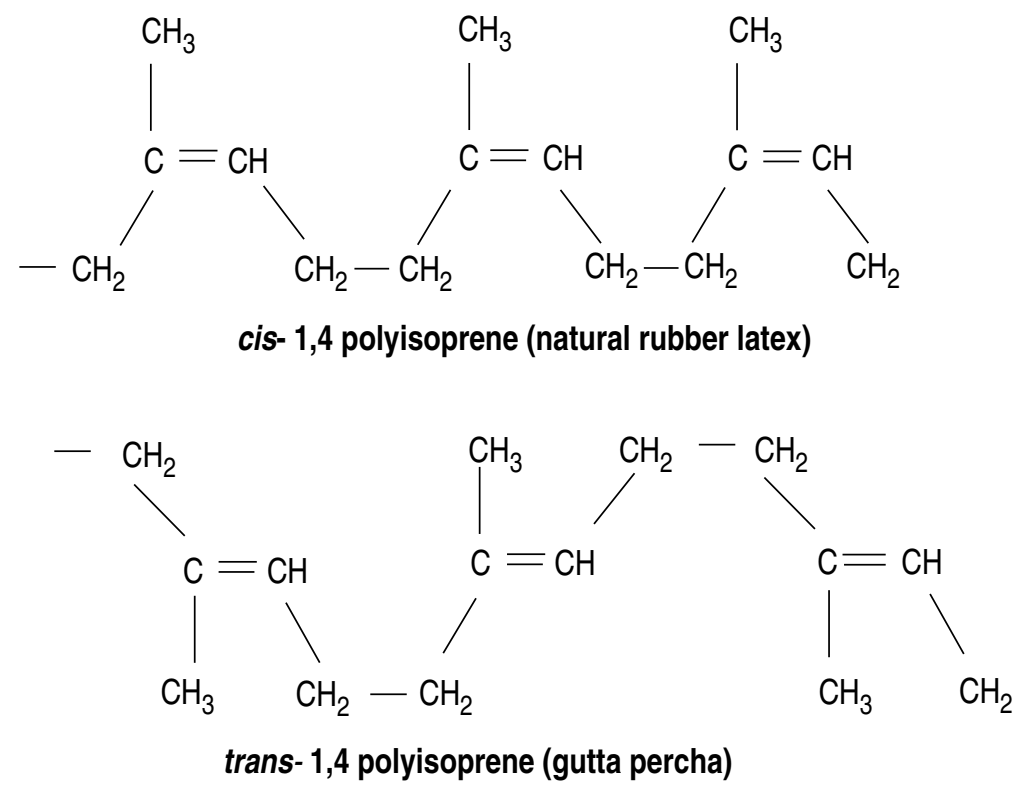

Fig. 1. - Chemical structure of natural rubber latex (cis- 1,4 polyisoprene) as opposed to gutta percha (trans-1,4 polyisoprene),

$(5 \mathrm{kDa})$ and hevein preproprotein (or prohevein, $20 \mathrm{kDa})$ are major proteins of the lutoid bodies. Hevein has chitinbinding properties and inhibits the growth of chitincontaining fungi [19]. Hevamine (29 kDa), an enzyme with lysozyme/chitinase activity, has also been isolated from the lutoids [20]. NRL contains a number of other proteins, whose structure and function have not been identified.

\section{Processing}

Ammonia is added to the fresh latex obtained by tapping the rubber tree to prevent coagulation and putrefaction. The resulting substance is then concentrated to obtain a $60 \%$ rubber content by centrifugation. Further processing of concentrated NRL varies considerably according to the desired properties of the finished product, but usually includes the following three steps: compounding, coagulation and vulcanization. Compounding involves the addition of a variety of chemicals, including antioxidants (e.g. paraphenylenediamine), accelerators (e.g. zinc oxide, thiurams, dithiocarbamates, mercaptobenzothiazole), fillers, pigments, emulsifiers and other ingredients. Some of these compounding agents can cause delayed type-IV hypersensitivity [21]. The concentrated liquid NRL is converted to a solid form during the coagulation, or curing, process by dehydration and/or addition of acids, metal ions, or surface active agents. Vulcanization consists of a heat-catalysed cross-linking of the cis- 1,4 polyisoprene chains by sulphur bridges; this imparts the characteristic property of rubber elasticity. NRL articles are produced by dipping or extrusion/compression moulding. Typically, gloves are manufactured by dipping porcelain formers, pretreated with a coagulant (e.g. calcium nitrate) and a releasing agent (cornstarch powder), into the compounded liquid NRL. The gloves are then passed through ovens to complete coagulation of NRL, and through waterbaths to extract water-soluble proteins and processing chemicals. Finally, they undergo the vulcanization process. The gloves can be depowdered through a chlorination wash.

\section{Pathophysiology}

The first well-documented case of asthma induced by NRL gloves was reported by SEATON et al. [3] who postulated that the offending agent was terpene vapour. There is now convincing evidence both from in vitro and in vivo experiments that NRL proteins can bind to cornstarch glove powder [7], and function as airborne allergens inducing respiratory reactions through an IgE-mediated mechanism [5, 6, 9]. Maize allergens in cornstarch powder [22, 23], and ethylene oxide used for sterilization [24, 25], have been reported as possible causes of immediate allergic reactions to gloves, but these allergens have never been convincingly shown to induce asthma by specific inhalation challenges (SICs).

\section{NRL allergens}

The relevant NRL allergens are complex and yet incompletely characterized $[1,2,26]$. Immunoelectrophoretic studies conducted by several groups of investigators have identified IgE-binding proteins with molecular weights ranging $2-100 \mathrm{kDa}$ in raw NRL and eluates from NRL finished products [9, 27-34). Antigenic peptides with molecular weights of 10, 14, 20, 24, 30, and 55-66 kDa have been identified most consistently. Variations in protein antigen profiles may be due to differences in source materials. For instance, glove extracts contain protein antigens that are not detected in crude NRL and that could be formed during glove manufacture [29, 32]. Methods for extracting and identifying antigen from NRL products are also likely to affect the 
results. Furthermore, discrepancies may have resulted from differences in the immune sera (e.g. patients with spina bifida $v s$ health-care workers) used to detect antigenic proteins. Thus, the pattern of IgE response varies considerably between subjects with NRL allergy, possibly as a result of differences in the patients' mode of sensitization $[34,35]$. Although no clear association has been demonstrated between the pattern of IgE response to NRL proteins and a specific clinical syndrome of NRL allergy, a $27 \mathrm{kDa}$ antigen eliciting specific $\operatorname{IgE}$ in subjects with spina bifida but not in health-care workers has been shown in some studies [33]. Immunoglobulin G4 (IgG4) antibodies against NRL proteins have also been detected in the serum of NRL-sensitive subjects [36], but their pathophysiological relevance remains to be determined. Among the proteins identified in NRL, rubber elongation factor $(14 \mathrm{kDa})$ and prohevein $(20 \mathrm{kDa})$ have so far been documented as relevant allergens involved in IgE-mediated allergy to NRL [37, 38].

Several reports indicate that NRL allergens may crossreact with latex from the weeping fig (Ficus benjamina) [39], and various fruits (banana, avocado, passion fruit, kiwi and chestnut) [40-44]. A recent study suggests that NRL and fruits have common epitopes on $30 \mathrm{kDa}$ proteins [45].

\section{Exposure to airborne NRL allergens}

Clinical manifestations of NRL allergy vary according to the route of NRL antigen presentation [46]. Cutaneous exposure to NRL causes local urticaria but may progress to systemic reactions. By contrast, mucosal, visceral and parenteral exposure usually lead to more severe systemic reactions. Anaphylactic reactions have been described during gynaecological, surgical and dental procedures [47-51], as well as during barium enema examinations using NRL balloon-tipped catheters [52, 53]. The possibility that glove-powder particles act as carriers of NRL allergens was first suggested by LAGIER et al. [5] and BAUR and JAEGER [6] based on inhalation challenges. This was further substantiated by TuRJANMAA $e t$ al. [7] who demonstrated that glove powder contains NRL allergens. Using an inhibition assay, SwANSON et al. [11] recently quantified airborne NRL allergens collected with personal and area samplers at various work sites in a hospital. The amount of airborne NRL allergens roughly correlated with the frequency of glove use, although considerable variation was found among subjects with the same type of job. Substantial amounts of allergens were recovered from coats and surgical scrub suits, suggesting that resuspension from clothing and settled dust may lead to secondary or even remote inhalation exposure.

Twenty percent of airborne powder particles were in a respirable size and, therefore, capable of causing asthma. The authors found that airborne allergens were predominantly of high molecular weight $(70-100 \mathrm{kDa})$, although it has not yet been shown that subjects with asthma are more specifically sensitized to these allergens as compared with subjects with other symptoms of NRL allergy. Workplace exposure to airborne NRL has also been documented to result from inhalation of dust generated by grinding NRL articles [13]. According to our clinical experience, nonoccupational exposure to airborne NRL is rare, but it may result from bursting toy balloons. A recent study, however, provides preliminary evidence that NRL allergens could be present in respirable particulate air pollution resulting from the abrasion of rubber tyres on road surfaces, although their role in the development of respiratory hypersensitivity to NRL requires further investigation [54].

\section{Epidemiology}

\section{Prevalence}

Populations at increased risk for developing NRL hypersensitivity include healthcare workers, rubber-industry workers and subjects undergoing multiple surgical procedures, especially children with spina bifida and urogenital abnormalities (table 1). Prevalence figures for NRL allergy have ranged $2.9-17 \%$ among hospital employees $[14,55-58]$, and $11 \%$ among glove-manufacturing workers [8], in studies using skin prick-tests (SPT) as the confirmatory procedure. NRL allergy has been demonstrated in $32-50 \%$ of children with spina bifida by SPT $[59,60]$, or serological testing [2]. The prevalence of sensitization to NRL in the general population ranged $0-9 \%$ according to the atopic status of the selected populations (table 1) $[55,57,59,61]$. The dramatic rise in incidence of sensitization to NRL observed during the last decade is probably related to the increased use of NRL devices as a protective barrier against viral infections. Other possible determinant factors are the increased recognition of NRL allergy by exposed workers and clinicians, changes in manufacturing methods, and discontinuation of steam sterilization.

NRL-induced asthma has been described primarily among workers manufacturing or using gloves. Occupational asthma has been diagnosed in $6 \%$ of workers in a glove-manufacturing plant on the basis of positive SPT associated with changes in spirometry and nonspecific bronchial responsiveness related to workplace exposure, although the diagnosis was not confirmed by SIC [8]. We recently surveyed 273 out of 289 employees of a primary care hospital, including nurses, members of the cleaning staff, and laboratory technologists, in order to assess the prevalence of occupational asthma due to NRL [14]. The study included a standard questionnaire, SPT, assessment of nonspecific bronchial responsiveness to histamine and SIC with latex gloves in a stepwise protocol. SICs with latex gloves elicited an asthmatic reaction (four immediate and three dual reactions) in 7 out of 12 subjects with NRL allergy. This survey shows that NRL-induced asthma represents a significant respiratory health hazard as it may occur in $2.5 \%$ (95\% confidence interval (95\% CI) $1.0-5.2 \%$ ) of hospital employees. Furthermore, our data indicate that asthma is a fairly common manifestation of NRL allergy among healthcare workers. These findings are consistent with those 
Table 1. - Prevalence of allergy and occupational asthma due to NRL

\begin{tabular}{|c|c|c|c|c|}
\hline Populations & $\begin{array}{l}\text { Subjects studied } \\
\text { n }\end{array}$ & $\begin{array}{c}\text { NRL } \\
\text { allergy* } \\
\%\end{array}$ & $\begin{array}{c}\text { NRL-induced } \\
\text { occupational } \\
\text { asthma } \\
\%\end{array}$ & [Ref] \\
\hline \multicolumn{5}{|l|}{ NRL industry workers } \\
\hline Glove manufacture & 64 & 10.9 & 6.0 & [8] \\
\hline Doll manufacture & 22 & 9.0 & 9.0 & [13] \\
\hline \multicolumn{5}{|l|}{ Health-care workers } \\
\hline Hospital employees (operating rooms, laboratory) & 512 & 2.8 & & [55] \\
\hline Operating room nurses & 71 & 5.6 & & [55] \\
\hline Surgeons & 54 & 7.4 & & [55] \\
\hline Operating room nurses & 197 & 10.7 & & [56] \\
\hline Physicians (surgeons, anaesthesiologists, laboratory) & 101 & 9.9 & & [57] \\
\hline Hospital employees & 224 & 16.9 & & [58] \\
\hline Hospital employees & 273 & 4.7 & 2.5 & [14] \\
\hline \multicolumn{5}{|l|}{ Multiple surgical procedures } \\
\hline Spina bifida children & 25 & 32.0 & & [59] \\
\hline Spina bifida children & 83 & 50.6 & & [60] \\
\hline Spina bifida children & 93 & 37.6 & & [2] \\
\hline \multicolumn{5}{|l|}{ General population } \\
\hline Patients of a dermatology clinic & 130 & 0.8 & & [55] \\
\hline "Control subjects" & 207 & 0 & & [61] \\
\hline Nonatopics (allergology clinic) & 272 & 0.4 & & [59] \\
\hline Atopics (allergology clinic) & 180 & 9.4 & & [59] \\
\hline Atopics (allergology clinic) & 100 & 3.0 & & [57] \\
\hline
\end{tabular}

*: skin-prick tests were used as the confirmatory procedure in order to establish IgE sensitization to NLR except in one study (see [2]) based on in vitro assessent of specific IgE. NLR: natural rubber latex.

from BuBAK et al. [62] who found that $22 \%$ of healthcare workers evaluated for NRL allergy reported asthma symptoms. Respiratory reactions to NRL are likely to occur in nonmedical environments where NRL gloves are used as a protection against irritant chemicals [28, 63], although epidemiological data are lacking.

Although powdered NRL gloves represent the most frequent source of exposure to airborne NRL, the possibility of respiratory hypersensitivity reactions to NRL in other industrial environments should be considered. In a recent survey, NRL-induced asthma was documented in 2 out of 22 workers exposed to NRL dust in a latex-doll manufacturing plant [13].

\section{Risk factors}

Both environmental and host factors can predispose to immunological sensitization and asthma due to high molecular weight agents [64]. Factors determining the development of asthma among subjects with NRL allergy are unknown. A clear dose-response relationship between exposure to NRL and IgE-mediated sensitization has not yet been demonstrated [14], although the highest prevalence rates of NRL allergy have been found in operating room nurses and physicians, who presumably have the highest level of exposure [55, 56]. Assessment of exposure based on self-reported use of NRL gloves may not reflect the actual level of exposure [14], since colleagues working in the same environment represent a significant source of airborne allergen. Immunological techniques for quantitative assessment of environmental NRL allergens [11] could help to further clarify exposure-response relationships.

In addition to repeated exposure to NRL products, atopy seems to be the principal determinant for the development of NRL sensitization. Atopy (defined either by SPT to common inhalant allergens or by history) is 2.24.9 fold more frequent in health-care personnel with NRL allergy than in their co-workers without NRL allergy [14, 55-58]. However, the predictive value of atopy with regard to the presence of immunologic sensitization and occupational asthma due to NRL is low. In our survey, only $10 \%$ of atopic hospital workers had NRL allergy [14].

Pre-existing dermatitis of the hands, frequently caused by the nonlatex components of rubber gloves [21], is thought to enhance the risk of NRL allergy by facilitating the transcutaneous passage of NRL proteins. Hand eczema has been found 2.3-4.2 fold more frequently in subjects with NRL allergy than in their nonallergic coworkers $[14,55,58]$. At present, no epidemiological data exist to support the inclusion of allergy to fruits as an independent risk factor for NRL allergy, although in some cases allergic manifestation to fruit ingestion may precede the onset of NRL allergy [41, 43]. 


\section{Diagnosis}

Several diagnostic procedures can be used to confirm occupational asthma, including history-taking, immunological testing, and direct assessment of the relationship between exposure and bronchial reaction through monitoring of peak expiratory flow rates (PEFR) or SIC [65].

\section{History}

The clinical history proved to be a sensitive but not a specific diagnostic tool in the individual assessment of occupational asthma [66]. In the case of NRL-induced asthma among health-care workers, it is our experience that the clinical history is often misleading. The workrelatedness of asthmatic symptoms can be confused by the fact that exposure to airborne NRL allergens is intermittent. Hospital workers have varied and sliding shifts, and the type of professional activity varies greatly from one day to the next and from one shift to another within the same hospital department. On the other hand, NRL often remains unidentified as the responsible agent because exposure may be indirect, resulting from inhalation of NRL allergens disseminated in the air by co-workers using latex gloves. We observed one such case where occupational asthma was caused exclusively by indirect exposure to NRL allergens in a medical secretary, who did not use gloves [16]. Subjects with skin allergy to NRL often ascribe their asthma to substances other than NRL because they still experience asthma at work despite having switched to NRL-free gloves.

\section{Immunological tests}

At present, in vitro measurement of NRL-specific IgE using radioallergosorbent test (RAST) or enzyme-linked immunosorbent assay (ELISA) methods is less reliable than SPT. The sensitivity of in vitro tests ranged $14-84 \%$ as compared with SPT [9, 56, 59, 60, 67]. Although anaphylactic events have been reported after SPT with NRL extracts [60], most investigators agree that SPT can be performed safely, and should be, for the time being, the recommended procedure for demonstrating IgE sensitization to NRL. Nevertheless, because our knowledge of the major NRL allergens is incomplete, in vivo and in vitro immunological tests are not yet standardized. The reliability of commercially available and home-made NRL extracts has not been thoroughly assessed.

Positive SPTs to NRL reflect IgE-mediated sensitization, but do not necessarily indicate that the target organ (i.e. the bronchi) is involved. We have observed NRLallergic subjects with urticaria and rhinitis who did not show bronchial reactivity to NRL during prolonged SIC with NRL gloves, even though they had marked nonspecific bronchial hyperresponsiveness.

\section{Assessment of exposure-asthma relationship}

Diagnosing asthma due to occupational agents, including NRL, has considerable medical, professional, and financial consequences [68], and should, therefore, rely on the most reliable tests [65]. Serial monitoring of PEFR is an easy method for demonstrating workplace asthma, but it may not always allow for the precise identification of the causal agent. Such identification, however, is essential for prevention, because health-care workers are exposed to a variety of substances that can cause asthma, including biocides and pharmaceutical agents [69]. SIC remains a useful method in establishing the diagnosis of occupational asthma due to NRL [10] and other workplace agents [65]. Subjects have been challenged either by handling NRL gloves $[5,9,14,15]$, or by inhaling aqueous extracts of gloves $[4,10]$. At present, no standardized methodology exists for performing SIC with NRL, since standardization would require quantifying the amount of allergen administered to the subjects. We choose to expose health-care workers by having them handle NRL gloves [10, 14, 15], because this method is more likely to reproduce the mode of exposure encountered in the workplace (i.e. airborne particles) than is the inhalation of nebulized glove extracts proposed by some investigators [4, 10]. Recently designed aerosolization devices [70] could be used to produce steady concentrations of respirable NRL dust. Quantitative assessment of airborne NRL allergens are warranted in order to compare the level of exposure during SIC to that found in the workplace [11].

So far, the "handling" method has proved to be both simple and safe. After a control exposure to vinyl gloves, the subjects are asked to open glove bags and handle the gloves in a challenge room while they wear vinyl gloves in order to avoid unnecessary skin reactions. The duration of exposure is progressively increased and spirometry is monitored in order to prevent unduly severe asthmatic reactions. Using this methodology, we have challenged 27 health-care workers with NRL allergy, including 11 who did not report a history of occupational asthma. Exposure to NRL gloves elicited an asthmatic reaction in 15 out of 16 subjects with a history of occupational asthma and in 5 out of 11 subjects without such a history. These results, together with those of a previous survey of occupational asthma due to psyllium among nurses [71], suggest that, at least in the case of healthcare workers, SICs can be more sensitive than the clinical history, and allow for the identification of subjects with latent bronchial reactivity to NRL. SICs caused no systemic adverse events, even among the six subjects who had a history of anaphylactic reaction after exposure to NRL or ingestion of fruits. The pattern of bronchial responses to NRL gloves included immediate $(n=14)$, dual $(n=5)$, and isolated late $(n=1)$ reactions. Isolated late reactions have also been described in subjects challenged with low doses of common inhalant allergens [72].

\section{Management}

At present, we lack specific information on the outcome of subjects with NRL-induced asthma. Most studies on occupational asthma caused by other substances have shown that persistence of exposure to the causal 
agent resulted in worsening of airway obstruction and nonspecific bronchial hyperresponsiveness [73], even in subjects whose exposure to the offending agent was reduced $[74,75]$. Therefore, complete and definitive removal from exposure is the most effective treatment, and it should be strongly recommended to subjects with NRLinduced asthma. However, strict avoidance of exposure is difficult to implement in the case of health-care workers with asthma due to NRL gloves. Firstly, personal avoidance of NRL gloves does not prevent exposure to airborne NRL, which may result from inhalation of NRL-contaminated cornstarch powder particles disseminated in the air by co-workers handling NRL gloves [11]. Secondly, widespread use of NRL-free gloves is so far precluded. Vinyl gloves are not as strong as latex gloves, nor do they provide a satisfactory tactile feel. Other synthetic elastomer gloves have satisfactory mechanical and tactile properties, but are much more expensive than NRL gloves. Hence, strict avoidance of exposure to airborne NRL most often means change of jobs, which can have considerable socioeconomic repercussions for health-care workers, as they are often highly trained professionals.

When affected subjects do not agree to complete removal from NRL exposure, procedures aimed at reducing the level of airborne NRL allergens in the working environment should be considered. It has been shown that the protein and allergen content can be lowered by washing the gloves during the manufacturing process [76, 77], although it is doubtful that NRL gloves can be $100 \%$ allergen-free. Furthermore, it is not known whether the allergenic proteins found in NRL contribute to the physical properties of finished products, nor whether the removal of these proteins will alter these physical properties. Lowering the amount of cornstarch powder on gloves may also contribute to a reduction in the release of airborne latex allergens [11, 12].

Using inhalation challenges, we recently evaluated in vivo whether NRL gloves with a reduced protein content could be effective in the prevention of asthmatic reactions in health-care workers with NRL-induced asthma [15]. Eight subjects were exposed by handling the brand of powdered NRL gloves causing asthma at work and various brands of gloves with a lower protein content, either powdered, low-powdered, or nonpowdered. Exposure to low-protein gloves, either powdered or not, did not elicit bronchial response in 6 out of 8 subjects. In the remaining two subjects, only one brand of lowpowdered, low-protein gloves induced an asthmatic reaction. Even in these two subjects, the low-powdered gloves resulted in a reduced bronchial response, since the duration of exposure required to provoke an asthmatic reaction was significantly longer than for the regular powdered gloves. This study shows that exposure to gloves with a lower protein content reduces, but does not abolish, the risk of asthmatic reactions in health-care workers with NRL-induced asthma. Furthermore, our data suggest that reducing the amount of cornstarch powder alone should not be considered sufficient to prevent asthmatic reactions, since low-powdered gloves induced asthma in two subjects whilst powdered gloves did not.

NRL gloves with reduced content in allergen and/or powder are often referred to as "hypoallergenic" by manufacturers, although this label is not precisely defined and requires to be regulated. The use of "hypoallergenic" gloves should be recommended to the colleagues of subjects with NRL-induced asthma when they do not accept the switch to NRL-free gloves. However, the safety of such "hypoallergenic" gloves should be properly evaluated on an individual basis, since highly sensitive subjects may still develop asthma after prolonged exposure [15].

From a practical point of view, subjects with NRLinduced asthma should be encouraged to use only NRLfree gloves. Furthermore, every effort should be made to reduce indirect exposure to airborne NRL when complete avoidance cannot be achieved. Examination gloves are a significant source of airborne NRL outside operating rooms and should, therefore, be systematically replaced by vinyl or other synthetic gloves. Sterile surgical gloves

Table 2. - Nonexhaustive list of NRL-free gloves and NRL gloves with a reduced protein content

\begin{tabular}{llll}
\hline Trade name & Type & Material & Manufacturer \\
\hline $\begin{array}{l}\text { NRL-free gloves } \\
\text { Dermaprene }\end{array}$ & S & Neoprene & \\
Neolon & S & Neoprene & Ansell Medical \\
Tactylon & S/E & Styrene ethylene butylene & Becton-Dickinson \\
Triflex & S & Polyvinylchloride & Baxtice \\
SensiCare & E & Polyvinylchloride & Becton-Dickinson \\
TruTouch & E & Polyvinylchloride & Becton-Dickinson \\
& & & \\
NRL gloves with a lower protein & content & & \\
Gammex & S Powdered & NRL & Ansell Medical \\
SensiTouch* & S Powdered & NRL & Ansell Medical \\
NuTex* & S Non-powdered & NRL & Ansell Medical \\
Triflex* & S Low-powdered & NRL & Baxter Healthcare Corp. \\
Sempermed Senso & S Powdered & NRL & Semperit \\
Sempermed Ultra & S Non-powdered & NRL & Semperit \\
\hline
\end{tabular}

NRL: natural rubber latex; S: sterile surgical gloves; E: nonsterile examination gloves. *: these brands of gloves have been tested using inhalation challenges in subjects with NRL-induced asthma (see [15]). Information included in this table has been provided by manufacturers. 
with a lower protein content should be used by all staff members working in the environment of affected subjects. However, further investigation is required in order to determine whether reduction of exposure to airborne NRL allergens makes it possible to prevent deterioration of asthma. Table 2 provides a non-exhaustive list of those NRL-free gloves and low-protein content gloves that are available in European countries. In addition to prevention of inhalation exposure, subjects with NRL-induced asthma should be instructed to avoid direct contact with NRL materials in everyday life according to recently published recommendations [2].

\section{Prevention}

The keystone of prevention should be primary prevention strategies aimed at controlling NRL exposure in order to avert IgE sensitization and asthma [78]. The use of NRL-free materials is undoubtedly the most effective means of preventing sensitization to NRL, but does not appear to be feasible at the present time for the above-discussed reasons. On the other hand, reducing exposure to NRL remains a challenging problem because the relevant allergens have not been precisely identified and characterized. Immunological methods for quantitative in vitro assessment of allergen content in NRL devices [77] have not yet been validated, and it remains uncertain whether their results correlate with the in vivo effects. On the other hand, the content in total protein of NRL products does not accurately reflect their allergenic content $[15,76,79]$. Furthermore, the threshold dose of airborne NRL causing bronchial sensitization is not known.

Secondary prevention involves identification of disease at an early stage in order to minimize long-term impairment and disability. The high prevalence of NRL allergy among exposed workers justifies regular medical surveillance by immunological assessment and questionnaire. Although the natural history of NRL-induced asthma remains largely unknown, there is some suggestion that health-care workers have a progression of symptoms from cutaneous reactions to rhinoconjunctivitis and asthma. Among 14 subjects with confirmed NRLinduced asthma, we found that the inaugural symptomatology was urticaria in four subjects, urticaria associated with rhinitis in six subjects, rhinitis in 2 subjects and asthma in two subjects. Rhinitis preceded the onset of asthma by an average of 6 months (range, 2-20 months). At present, it is not known whether subjects with urticaria and/or rhinitis will develop asthma if they remain exposed to low levels of airborne NRL. It has been documented that in sensitized subjects, repeated exposure to low doses of common inhalant allergens that do not cause asthmatic reactions can induce an increase in nonspecific bronchial hyperresponsiveness [80]. Hence, follow-up studies of subjects with asymptomatic bronchial reactivity to NRL are required to determine whether persistence of exposure will result in worsening of bronchial hyperresponsiveness and clinically evident asthma.

\section{Conclusions}

In conclusion there is accumulating evidence that airborne NRL represents a significant cause of occupational asthma among workers manufacturing NRL materials and those using NRL gloves. Considering the number of exposed workers throughout the world, especially health-care providers, NRL-induced asthma should be considered a cause of major medical concern. Furthermore, the condition may lead to considerable socioeconomic consequences. Preventive strategies are, therefore, urgently required to reduce exposure to NRL allergens below the level that elicits reactions in already sensitized subjects and, preferably, below the level that initiates sensitization.

Further characterization of relevant NRL allergens should be considered a priority, since greater knowledge of the relevant allergens will make it possible to: 1) develop methods for quantitative assessment of allergen content in NRL devices and workplace environments; 2) help glove manufacturers to reduce the NRL-allergen content of their products; and 3) establish international quality standards and precise labelling regulations for NRL gloves. Alternatively, the development of synthetic rubber gloves with satisfactory mechanical properties at lower expense should be encouraged. Prospective studies are warranted in order to determine the natural history and risk factors of NRL-induced asthma and to assess the cost and effectiveness of preventive measures.

Acknowledgement: The author wishes to thank J.L. Malo and Y. Sibille for their thoughtful comments, and L Schubert for her excellent editorial work.

\section{References}

1. Levy DA, Charpin D, Pecquet C, Leynadier F, Vervloet D. Allergy to latex. Allergy 1992; 47: 579-587.

2. Slater JE. Latex allergy. J Allergy Clin Immunol 1994; 94: 139-149.

3. Seaton A, Cherrie B, Turnbull J. Rubber glove asthma. Br Med J 1988; 296: 531-532.

4. Marcos C, Lázaro M, Fraj J, et al. Occupational asthma due to latex surgical gloves. Ann Allergy 1991; 67: 319-323.

5. Lagier F, Badier M, Charpin D, Martigny J, Vervloet D. Latex as aeroallergen. Lancet 1990; ii: 516-517.

6. Baur X, Jaeger D. Airborne antigens from latex gloves. Lancet 1990; 335: 912.

7. Turganmaa K, Reunala T, Alenius H, Brummer-Korvenkontio H, Palosuo T. Allergens in latex surgical gloves and glove powder. Lancet 1990; 336: 1588.

8. Tarlo SM, Wong L, Roos J, Booth N. Occupational asthma caused by latex in a surgical glove manufacturing plant. J Allergy Clin Immunol 1990; 85: 626631 .

9. Jaeger D, Czuppon AB, Baur X. Latex-specific proteins causing immediate-type cuntaneous, nasal, bronchial, and systemic reactions. J Allergy Clin Immunol 1992; 89: 759-767.

10. Pisati G, Baruffini A, Bernabeo F, Stanizzi R. Bronchial provocation testing in the diagnosis of occuptional asthma due to latex surgical gloves. Eur Respir J 1994; 7: 332-336. 
11. Swanson MC, Bubak ME, Hunt LW, Yunginger JW, Warner MA, Reed CE. Quantification of occupational latex aeroallergens in a medical center. J Allergy Clin Immunol 1994; 94: 445-451.

12. Tarlo SM, Sussman G, Contala A, Swanson MC. Control of airborne latex by use of powder-free latex gloves. J Allergy Clin Immunol 1994; 93: 985-989.

13. Orfan NA, Reed R, Dykewicz MS, Ganz M, Kolski GB. Occupational asthma in a latex doll manufacturing plant. J Allergy Clin Immunol 1994; 94: 826-830.

14. Vandenplas O, Delwiche JP, Evrard G, et al. Prevalence of occupational asthma due to latex among hospital personnel. Am J Respir Crit Care Med 1995; 151: 54-60.

15. Vandenplas O, Delwiche JP, Depelchin S, Sibille Y, Vande Weyer R, Delaunois L. Latex gloves with a lower protein content reduce bronchial reactions in subjects with occupational asthma due to latex. Am J Respir Crit Care Med 1995; 151: 887-891.

16. Vandenplas O, Delwiche JP, Sibille Y. Occupational asthma due to latex in a hospital administrative employee. Thorax (in press).

17. St Cyr DR. Rubber, natural. In: Kirk-Othmer, ed. Encyclopedia of Chemical Technology. New York, John Wiley \& Sons, 1982: pp. 468-491.

18. Dennis MS, Light DR. Rubber elongation factor from Hevea braziliensis. Identification, characterization, and role in rubber biosynthesis. J Biol Chem 1989; 264: 18608-18617.

19. Lee H, Broekaert WF, Raikhel NV. Co- and posttranslational processing of the hevein preproprotein latex of the rubber tree (Hevea braziliensis). J Biol Chem 1991; 24: 15944-15948.

20. Jekel PA, Hartmann JBH, Beintma JJ. The primary structure of hevamine, an enzyme with lysozyme/chitinase activity from Hevea braziliensis latex. Eur J Biochem 1991; 200: 123-130.

21. Fisher AA. Allergic contact reactions in health personnel. J Allergy Clin Immunol 1992; 90: 729-738.

22. Van der Meeren HLM, Van Erp PEL. Life-threatening contact urticaria from glove powder. Contact Dermatitis 1986; 14: 323-324.

23. Fisher AA. Contact urticaria due to cornstarch surgical glove powder. Cutis 1986; 38: 307-308.

24. Moneret-Vautrin DA, Laxenaire MC, Bavoux F. Allergic shock to latex and ethylene dioxide during surgery for spina bifida. Anesthesiology 1990; 73: 556-558.

25. Dugue P, Faraut C, Figueredo M, Bettendorf A, Salvadori $\mathrm{JM}$. Asthme professionnel à l'oxyde d'éthylène chez une infirmière. Presse Méd 1991; 20: 1455.

26. Ownby DR. Is rubber elongation factor the major allergen of latex? J Allergy Clin Immunol 1993; 92: 633-635.

27. Carrillo T, Cuevas M, Munoz T, Hinojosa M, Moneo I. Contact urticaria and rhinitis from latex surgical gloves. Contact Dermatitis 1986; 14: 69-72.

28. Morales C, Basomba A, Carreira J, Sastre A. Anaphylaxis produced by rubber glove contact: case reports and identification of the antigen involved. Clin Exp Allergy 1989; 19: 425-430.

29. Alenius H, Turjanmaa K, Palosuo T, Mäkinen-Kiljunen S, Reunala T. Surgical latex glove allergy: characterization of rubber protein allergens by immunoblotting. Int Arch Allergy Appl Immunol 1991; 96: 376-380.

30. Chambeyron C, Dry J, Leynadier F, Pecquet C, Thao TX. Study of the allergenic fractions of latex. Allergy 1992; 47: 92-97.

31. Mäkinen-Kiljunen S, Turjanmaa K, Palosuo T, Reunala
T. Characterization of latex antigens and allergens in surgical gloves and natural rubber by immunoelectrophoretic methods. J Allergy Clin Immunol 1992; 90: 230-235.

32. Slater JE, Chhabra SK. Latex antigens. J Allergy Clin Immunol 1992; 89: 673-678.

33. Alenius H, Palosuo T, Kelly K, et al. IgE reactivity to $14 \mathrm{kDa}$ and $27 \mathrm{kDa}$ natural rubber proteins in latexallergic children with spina bifida and other congenital anomalies. Int Arch Allergy Appl Immunol 1993; 102: 61-66.

34. Alenius H, Turjanmaa K, Mäkinen-Kiljunen S, Reunala T, Paluoso T. IgE immune response to rubber proteins in adult patients with latex allergy. J Allergy Clin Immunol 1994; 93: 859-863.

35. Kurup VP, Kelly KJ, Turjanmaa K, et al. Immunoglobulin $\mathrm{E}$ reactivity to latex antigens in the sera of patients from Finland and the United States. J Allergy Clin Immunol 1993; 91: 1128-1134.

36. Alenius H, Reunala T, Turjanmaa K, Palosuo T. Detection of IgG4 and IgE antibodies to rubber latex proteins by immunoblotting in latex allergy. Allergy Proc 1992; 13: $75-77$.

37. Czuppon AB, Rennert S, Engelke T, Meier H, Heber M, Baur X. The rubber elongation factor of rubber trees (Hevea brasiliensis) is the major allergen in latex. $J$ Allergy Clin Immunol 1993; 92: 690-697.

38. Alenius H, Kalkkinen N, Lukka M, et al. Prohevein from rubber tree is a major latex allergen. J Allergy Clin Immunol 1995; 95: A155 (Abstract).

39. Axelsson IGK, Johanson SGO, Larsson PH, Zetterström O. Characterization of allergenic components in sap extract from the weeping fig (Ficus benjamina). Int Arch Allergy Appl Immunol 1990; 91: 130-135.

40. Ceuppens JL, Van Durme P, Dooms-Goossens A. Latex allergy in patients with allergy to fruit. Lancet 1992; 339: 493.

41. M'Raihi ML, Charpin D, Pons A, Bongrand P, Vervloet D. Cross-reactivity between latex and banana. J Allergy Clin Immunol 1991; 87: 129-130.

42. Anibarro B, Garcia-Ara MC, Pascual C. Associated sensitization to latex and chestnut. Allergy 1993; 48: 130-131.

43. Rodriguez M, Vega F, Garcia MT, et al. Hypersensitivity to latex, chestnut and banana. Ann Allergy 1993; 70: 31-34.

44. Mäkinen-Kiljunen S. Banana allergy in patients with immediate-type hypersensitivity to natural rubber latex: characterization of cross-reacting antibodies and allergens. J Allergy Clin Immunol 1994; 93: 990-996.

45. Lavaud F, Prevost A, Cossart C, Guerin L, Bernard J, Kochman S. Allergy to latex, avocado pear, and banana: evidence for a $30 \mathrm{kD}$ antigen in immunoblotting. $J$ Allergy Clin Immunol 1995; 95: 557-564.

46. Sussman GL, Tarlo S, Dolovich J. The spectrum of IgE-mediated responses to latex. J Am Med Assoc 1991; 265: 2844-2847.

47. Axelsson JGK, Johansson SGO, Wrangsjö K. IgEmediated anaphylactoid reactions to rubber. Allergy 1987; 42: 40-50.

48. Turjanmaa K, Reunala T, Tuimala R, Karkkainen T. Allergy to latex gloves: unusual complication during delivery. Br Med J 1988; 297: 1029.

49. Leynadier F, Pecquet C, Dry J. Anaphylaxis to latex during surgery. Anaesthesia 1989; 44: 547-550.

50. Slater JE. Rubber anaphylaxis. N Engl J Med 1989; 320: $1126-1130$. 
51. Gold M, Swartz JS, Braude BM, Dolovich J, Shandling B, Gilmour RF. Intraoperative anaphylaxis: an association with latex sensitivity. J Allergy Clin Immunol 1991; 87: 662-666.

52. Lozynski OA, Dupuis L, Shandling B, Gilmour RF, Zimmerman B. Anaphylactoid and systemic reaction following saline enema administration: six case reports. Ann Allergy 1986; 56: 62-66.

53. Gelfand DW. Barium enemas, latex balloons, and anaphylactic reactions. Am J Roentgenol 1991; 156: 12.

54. Williams PB, Buhr MP, Weber RW, Volz MA, Koepke JW, Selner JC. Latex allergen in respirable particulate air pollution. J Allergy Clin Immunol 1995; 95: 88-95.

55. Turjanmaa K. Incidence of immediate allergy to latex gloves in hospital personnel. Contact Dermatitis 1987; 17: 270-275.

56. Lagier F, Vervloet D, Lhermet I, Poyen D, Charpin D. Prevalence of latex allergy in operating room nurses. J Allergy Clin Immunol 1992; 319: 319-322.

57. Arellano R, Bradley J, Sussman G. Prevalence of latex sensitization among hospital physicians occupationally exposed to latex gloves. Anesthesiology 1992; 77: 905908.

58. Yassin MS, Lierl MB, Fisher TJ, O'Brien K, Cross J, Steinmetz C. Latex allergy in hospital employees. Ann Allergy 1994; 72: 245-249.

59. Moneret-Vautrin D, Beaudouin E, Widmer S, et al. Prospective study of risk factors in natural rubber latex hypersensitivity. J Allergy Clin Immunol 1993; 92: 668-677.

60. Kelly KJ, Kurup V, Zacharisen M, Resnick A, Fink JN. Skin and serologic testing in the diagnosis of latex allergy. J Allergy Clin Immunol 1993; 91: 1140-1145.

61. Pecquet C, Leynadier F, Dry J. Contact urticaria and anaphylaxis to natural rubber. J Am Acad Dermatol 1990; 22: 631-633.

62. Bubak ME, Reed CE, Fransway AF, et al. Allergic reactions to latex among health-care workers. Mayo Clin Proc 1992; 67: 1075-1079.

63. Fernandez de Corres L, Moneo I, Munoz D, et al. Sensitization from chestnuts and bananas in patients with urticaria and anaphylaxis from contact with latex. Ann Allergy 1993; 70: 35-39.

64. Venables KM. Epidemiology and the prevention of occupational asthma (Editorial). Br J Ind Med 1987; 44: 73-75.

65. Cartier A. Definition and diagnosis of occupational asthma. Eur Respir J 1994; 7: 153-160.
66. Malo JL, Ghezzo H, L'Archevêque J, Lagier F, Perrin B, Cartier A. Is the clinical history a satisfactory means of diagnosing occupational asthma? Am Rev Respir Dis 1991; 143: 528-532.

67. Turjanmaa K, Reunala T, Räsänen L. Comparison of diagnostic methods in latex surgical glove contact urticaria. Contact Dermatitis 1988; 19: 241-247.

68. Dewitte JD, Chan-Yeung M, Malo JL. Medicolegal and compensation aspects of occupational asthma. Eur Respir $J$ 1994; 7: 969-980.

69. Hayes JP, Fitzgerald MX. Occupational asthma among hospital health-care personnel: a cause for concern? Thorax 1994; 49: 198-200.

70. Cloutier Y, Lagier F, Lemieux R, et al. New methodology for specific inhalation challenges with occupational agents in powder form. Eur Respir J 1989; 2: 769-777.

71. Malo JL, Cartier A, L'Archevêque J, et al. Prevalence of occupational asthma and immunologic sensitization to psyllium among health personnel in chronic care hospitals. Am Rev Respir Dis 1990; 142: 1359-1366.

72. Ihre E, Axelsson IGK, Zetterström O. Late asthmatic reactions and bronchial variability after challenge with low doses of allergen. Clin Allergy 1988; 18: 557-567.

73. Chan-Yeung M. Occupational asthma. Chest 1990; 98: 148S-161S.

74. Côté J, Kennedy S, Chan-Yeung M. Outcome of patients with cedar asthma with continuous exposure. Am Rev Respir Dis 1990; 141: 373-376.

75. Banks DE, Rando RJ, Barkman HW. Persistence of toluene diisocyanate-induced asthma despite negligible workplace exposures. Chest 1990; 97: 121-125.

76. Leynadier F, Tran Xuan T, Dry J. Allergenicity suppression in natural latex surgical gloves. Allergy 1991; 46: 619-625.

77. Yunginger JW, Jones RT, Fransway AF, Kelso JM, Warner MA, Hunt LW. Extractable latex allergens and proteins in disposable medical gloves and other rubber products. J Allergy Clin Immunol 1994; 93: 836-842.

78. Venables KM. Preventing occupational asthma. $\mathrm{Br} J$ Ind Med 1992; 49: 817-819.

79. Turjanmaa K, Laurila K, Mäkinen-Kiljunen S, Reunala T. Rubber contact urticaria: allergenic properties of 19 brands of latex gloves. Contact Dermatitis 1988; 19: 362-367.

80. Ihre E, Zetterstrom O. Increase in nonspecific bronchial responsiveness after repeated inhalation of low doses of allergen. Clin Exp Allergy 1993; 23: 298-305. 